\title{
Correlation of HTLV-1 proviral load and lymphocyte proliferation from asymptomatic HTLV-1-positive patients and HAM/TSP patients associated or not to skin disorders
}

\author{
Renata Okajima ${ }^{1,2^{*}}$, Jerusa Smid ${ }^{1}$, Alberto JS Duarte ${ }^{3}$, Augusto Cesar Penalva de Oliveira ${ }^{1}$, Jorge Casseb ${ }^{1,4}$, \\ José Antonio Sanches Junior ${ }^{2}$
}

From 16th International Conference on Human Retroviruses: HTLV and Related Viruses

Montreal, Canada. 26-30 June 2013

This study evaluated the prevalence of skin diseases among HTLV-1 infected and the relation between HTLV-1 proviral load, and CD4+ and CD8+ T cells count among, regardless of clinical status, with or without associated skin disorders.193 HTLV-1-infected subjects were studied. Patients were submitted to a complete dermatological examination, lymphocyte proliferation assay (LPA), assay for HTLV-1 proviral load, CD4+ and CD8 + T cells count. A total of 147 patients had an abnormal skin condition; 116 (79\%) of these patients also had skin disorder associated with HTLV-1 infection (SDHTLV-1) (xerosis/ichthyosis or seborrheic dermatitis. The most prevalent SD-HTLV-1 was xerosis/acquired ichthyosis (49\%), followed by seborrheic dermatitis (27\%). Three of them had the association of adult onset IDH and HAM/TSP. The patients with SD-HTLV-1 were older (51 vs. 47 years), had a higher prevalence of myelopathy/tropical spastic paraparesis (HAM/TSP) $(\mathrm{p}=0.015)$, higher HTLV-1 proviral load $(\mathrm{p}=0.009)$ and had an increased 3-day basal LPA compared with patients without SD-HTLV-1 ( $\mathrm{p}=0.008)$. T CD4+ and CD8+ cells counts show no significance. When HAM/TSP patients were excluded from the analysis, the HTLV-1 proviral load showed a significant difference $(\mathrm{p}=0.021)$, while LPA showed no difference. There was a high prevalence of skin disorders (76\%) among HTLV-1-infected individuals, regardless of clinical status Initial HTLV-1 proviral load and age was higher in SD-HTLV-1 individuals, but

\footnotetext{
* Correspondence: renataokajima@uol.com.br

${ }^{1}$ HTLV-outpatient Clinic, Institute of Infectious Diseases "Emilio Ribas", São Paulo, Brazil

Full list of author information is available at the end of the article
}

the LPA showed an increase only in SD-HTLV-1 subjects with HAM/TSP.

\section{Authors' details}

"HTLV-outpatient Clinic, Institute of Infectious Diseases "Emilio Ribas", São Paulo, Brazil. Department of Dermatology, University of São Paulo Medical School, Brazil. ${ }^{3}$ Department of Clinical Pathology, University of São Paulo Medical School, Brazil. Institute of Tropical Medicine of São Paulo, University of São Paulo Medical School, Brazil.

Published: 7 January 2014

\section{doi:10.1186/1742-4690-11-S1-P16}

Cite this article as: Okajima et al:: Correlation of HTLV-1 proviral load and lymphocyte proliferation from asymptomatic HTLV-1-positive patients and HAM/TSP patients associated or not to skin disorders. Retrovirology 2014 11(Suppl 1):P16.

Submit your next manuscript to BioMed Central and take full advantage of:

- Convenient online submission

- Thorough peer review

- No space constraints or color figure charges

- Immediate publication on acceptance

- Inclusion in PubMed, CAS, Scopus and Google Scholar

- Research which is freely available for redistribution 